\title{
The balance between gluco- and mineralo-corticoid action critically determines inflammatory adipocyte responses
}

\author{
J Hoppmann, N Perwitz, B Meier, M Fasshauer ${ }^{1}$, D Hadaschik, H Lehnert and J Klein \\ Department of Internal Medicine I, University of Luebeck, Ratzeburger Allee 160, 23538 Luebeck, Germany \\ ${ }^{1}$ Department of Internal Medicine III, University of Leipzig, Philipp-Rosenthal-Straße 27, 04103 Leipzig, Germany \\ (Correspondence should be addressed to J Klein; Email: j.klein@uni-luebeck.de)
}

\begin{abstract}
Obesity is associated with chronic inflammation. Proinflammatory adipokines may promote metabolic disorders and cardiovascular morbidity. However, the key mechanisms leading to obesity-related inflammation are poorly understood. The corticosteroid metabolism in adipose tissue plays a crucial role in the pathogenesis of the metabolic syndrome. Both the glucocorticoid receptor (GR) and the mineralocorticoid receptor (MR) mediate corticosteroid action in adipose tissue. The significance of the interplay of these receptors in mediating an inflammatory adipokine response is virtually unexplored. In the present study, we investigated the differential roles of the GR and MR in controlling the key adipose tissue functions including inflammatory adipokine expression and adipogenesis using selective stimulation with receptor agonists, acute receptor knockdown via RNA interference and newly generated knockout adipose cell lines. Selective GR stimulation of white adipocytes
\end{abstract}

with dexamethasone inhibited the expression of interleukin 6 (IL6), monocyte chemoattractant protein-1 (MCP1 or CCL2 as listed in the MGI Database), tumour necrosis factor- $\alpha$, chemerin and leptin. By contrast, selective MR stimulation with aldosterone promoted the expression of IL6, plasminogen activator inhibitor 1, chemerin and leptin. Furthermore, in the presence of an acute GR knockdown as well as in GR knockout adipocytes, corticosterone increased the gene expression of the pro-inflammatory adipokines IL6 and MCP1. Whereas GR knockout adipocytes displayed a mildly impaired adipogenesis during early differentiation, MR knockout cells completely failed to accumulate lipids. Taken together, our data demonstrate a critical role for the balance between gluco- and mineralocorticoid action in determining adipocyte responses implicated in obesity-associated inflammation and cardiovascular complications.

Journal of Endocrinology (2010) 204, 153-164

\section{Introduction}

Obesity is associated with chronic subclinical inflammation, which is characterised by an increased production of pro-inflammatory cytokines and an altered endocrine and metabolic adipose tissue function (Wellen \& Hotamisligil 2005). The inflammatory state seen in obesity is considered to be responsible for the development of obesity-related disorders such as insulin resistance, hyperlipidaemia and cardiovascular morbidity (Pickup \& Crook 1998, Fernandez-Real \& Ricart 2003, Yudkin 2003). Increased plasma levels of interleukin 6 (IL6) and plasminogen activator inhibitor 1 (PAI-1 or SERPINE1 as listed in the MGI Database) considerably impair insulin sensitivity and predict the development of type 2 diabetes and cardiovascular disease in humans (Kern et al. 2001, Pradhan et al. 2001, Mertens \& Van Gaal 2002, Spranger et al. 2003). The pro-inflammatory monocyte chemoattractant protein-1 (MCP1 or CCL2 as listed in the MGI Database) which is elevated in obesity promotes monocyte infiltration in vessels and atherosclerotic plaques (Takahashi et al. 2003, Kanda et al. 2006). A vast array

of data also implicates the pro-inflammatory cytokine tumour necrosis factor- $\alpha(\mathrm{TNF}-\alpha)$ in the pathophysiology of the metabolic syndrome (Hotamisligil et al. 1993, 1995). The crosstalk between adipocytes and macrophages which infiltrate adipose tissue in obesity is considered to be crucial for the development of the pro-inflammatory state (Bluher 2008). To date, the molecular mechanisms that lead to obesity-related inflammation have not been elucidated completely.

Similarities between the metabolic syndrome and the glucocorticoid excess seen in Cushing's syndrome have led to the assumption that a deranged corticosteroid metabolism in adipose tissue plays a pivotal role in the development of obesity and associated metabolic and cardiovascular disorders. Indeed, adipose tissue-specific amplification of glucocorticoids by selective overexpression of $11 \beta$-hydroxysteroid dehydrogenase type 1 (HSD11B1) was shown to induce all the characteristic features of the metabolic syndrome in mice, including central obesity, diabetes, dyslipidaemia and hypertension (Masuzaki et al. 2001, 2003). In contrast, the inactivation of glucocorticoid action in adipose tissue enhances insulin sensitivity in these mice and protects them 
against obesity and diet-induced metabolic disease (Morton et al. 2004, Kershaw et al. 2005). Although cortisol plasma concentrations were shown not to be consistently elevated in obese people (Seckl et al. 2004), there is accumulating evidence for increased endogenous adipose tissue-specific glucocorticoid reactivation in human obesity (Mariniello et al. 2006, Alberti et al. 2007, Paulsen et al. 2007).

Glucocorticoid action in adipose tissue has long been considered to be exclusively mediated by the cytosolic glucocorticoid receptor (GR listed as NR3C1 in the MGI Database). Recently, it has been found that the mineralocorticoid receptor (MR listed as NR3C2 in the MGI Database) is also expressed in white adipocytes as well as in brown adipocytes (Rondinone et al. 1993, Zennaro et al. 1998). The MR possesses the same affinity for aldosterone and glucocorticoid hormones (Arriza et al. 1987). Considering that the glucocorticoid-deactivating enzyme HSD11B2 is not significantly expressed in adipose tissue, glucocorticoids can also act via the MR in adipocytes (Bujalska et al. 1997, Yang et al. 1997, Engeli et al. 2004). We and others have recently identified metabolic and endocrine functions of brown adipose tissue as a novel target for mineralocorticoid action (Viengchareun et al. 2001, Kraus et al. 2005). A previous study suggests an involvement of the MR in corticosteroid-induced adipogenesis (Caprio et al. 2007). Moreover, in recent murine in vivo and in vitro studies, stimulation of the $\mathrm{MR}$ was implicated to promote inflammation (Guo et al. 2008). To date, however, the physiological significance of the MR in mature adipocytes remains virtually unexplored and only little is known about the interplay of GR- and MR-mediated regulation of endocrine and metabolic adipocyte functions. Given that MR/GR dimers can mediate and differentially modulate corticosteroid action, it is even more difficult to dissect the separate roles of each receptor in controlling adipocyte responses.

In the present study, we therefore investigated the different roles of the corticosteroid receptors GR and MR in mediating an inflammatory adipokine response in mature adipocytes using three different approaches: selective stimulation with receptor agonists, acute knockdown of the GR in differentiated adipocytes using RNA interference and the generation and characterisation of GR and MR knockout cell lines from newborn homozygous knockout mice which die shortly after birth (Cole et al. 1995, Berger et al. 1998).

Our study demonstrates opposing and complementary effects of the GR and MR in regulating an inflammatory adipokine response. While selective GR activation induces an anti-inflammatory effect, GR knockdown and knockout as well as selective MR stimulation promote a pro-inflammatory adipokine profile in mature adipocytes. Our data provide support for the notion that the balance between GR and MR activation in adipocytes critically determines inflammatory and metabolic adipocyte responses. Selective corticosteroid receptor modulation may have therapeutic implications for the prevention and treatment of obesity and insulin resistance.

\section{Materials and Methods}

\section{Materials}

Aldosterone, corticosterone and dexamethasone were purchased from Sigma-Aldrich. Antibodies against the MR and GR were ordered from Santa Cruz Biotechnology (Santa Cruz, CA, USA), while antibodies against Pref- $1, \mathrm{C} / \mathrm{EBP} \alpha$ and $\mathrm{aP} 2$ as well as secondary anti-rabbit and anti-mouse antibodies were purchased from Cell Signaling Technology (Beverly, MA, USA). Primers for gene expression analyses were ordered from Biometra (Göttingen, Germany). All other materials were purchased from Sigma-Aldrich, unless stated otherwise.

\section{Generation of adipose cell lines}

Novel GR and MR knockout adipose cell lines from newborn homozygous knockout mice (ordered from the European Mouse Mutant Archive, Munich, Germany) as well as wild-type control cell lines were generated as originally described by Klein et al. (1999, 2002). In brief, $10 \mathrm{mg}$ interscapular brown fat was removed from newborn mice, minced and subjected to collagenase solution (1 mg collagenase in $1 \mathrm{ml}$ isolation buffer containing $0.123 \mathrm{mM} \mathrm{NaCl}$, $5 \mathrm{mM} \mathrm{KCl}, 1.3 \mathrm{mM} \mathrm{CaCl}_{2}, 5 \mathrm{mM}$ glucose, $100 \mathrm{mM}$ Hepes, $100 \mathrm{U} / \mathrm{ml}$ penicillin/streptomycin and $4 \%$ BSA (w/v)). Digestion was performed in a shaking water bath at $37^{\circ} \mathrm{C}$ for $40 \mathrm{~min}$. The digested tissue was filtered through a $100-\mu \mathrm{m}$ filter and centrifuged at $500 \mathrm{~g}$ for $5 \mathrm{~min}$. The supernatant was removed and the pellet was washed carefully. Centrifugation was repeated at $500 \mathrm{~g}$ for $5 \mathrm{~min}$. After resuspending the remaining pellet in culture medium, cells were transferred to plates and grown in a humidified atmosphere of $5 \% \mathrm{CO}_{2}$ $(\mathrm{v} / \mathrm{v})$ at $37^{\circ} \mathrm{C}$. The following day, cells were carefully washed with PBS. Subsequently, the culture medium was changed every day. After reaching 70\% confluence, cells were infected with the puromycin resistance-conferring retroviral vector pBabe coding for the SV40 Large T antigen for $24 \mathrm{~h}$. Cells were maintained in the culture medium for $48 \mathrm{~h}$ before a 3 -week selection with puromycin $(2 \mu \mathrm{g} / \mathrm{ml})$ was begun. Preadipocytes were split whenever reaching $80 \%$ confluence.

\section{Cell culture}

Cells were cultured as described previously (Klein et al. 1999, 2002). Immortalised white epididymal adipose cell lines as well as newly generated brown GR knockout, MR knockout and control wild-type cell lines were differentiated on 10-cm plates in DMEM supplemented with $20 \%$ foetal bovine serum (v/v), $4.5 \mathrm{~g} / 1$ glucose, $20 \mathrm{nM}$ insulin and $1 \mathrm{nM}$ triiodothyronine (differentiation medium) in a humidified atmosphere of $5 \% \mathrm{CO}_{2}(\mathrm{v} / \mathrm{v})$ at $37^{\circ} \mathrm{C}$. When preadipocytes reached confluence, cell differentiation was induced by $250 \mu \mathrm{M}$ indomethacine, $500 \mu \mathrm{M}$ isobutylmethylxanthine and $2 \mu \mathrm{g} / \mathrm{ml}$ dexamethasone for $20 \mathrm{~h}$ (induction medium). Subsequently, cells were grown in differentiation medium 
for another 6 days, and the culture medium was changed every day. Prior to the treatment with dexamethasone, aldosterone or corticosterone, adipocytes were serum starved in DMEM for $24 \mathrm{~h}$. All experiments were carried out by using at least three independent cell lines from passages 10 to 30 .

\section{$R N A$ interference}

Preadipocytes were cultured in six-well plates and differentiated as described above. The induction was performed in dexamethasone-depleted induction medium. On day 3 after induction, the adherent cells were carefully washed twice with PBS, trypsinised and resuspended in differentiation medium. Adipocytes were centrifuged at $800 \boldsymbol{g}$ for $5 \mathrm{~min}$. The supernatant was carefully removed and the pellet was dissolved in PBS. Centrifugation was repeated at $800 \boldsymbol{g}$ for $5 \mathrm{~min}$. For RNA silencing, adipocytes were mixed with the manufacturer's nucleofection reagent (Cell line nucleofector kit V, Lonza, Cologne, Germany) and 200 pmol GR-specific siRNA or negative control siRNA (scr. RNA) (Qiagen) in a total volume of $100 \mu$ l. Electroporation was performed using a Nucleofector (Lonza) according to the manufacturer's protocol. Transfected cells were cultured in a six-well plate for another 2 days and were subsequently starved in serumdepleted medium overnight. On day 6, adipocytes were treated with $100 \mathrm{nM}$ corticosterone for $2 \mathrm{~h}$. The extent of the receptor knockdown was quantified by western blot and quantitative real-time PCR.

\section{Western blot analysis}

Proteins were isolated from adipocytes using cell lysis buffer containing $2 \mathrm{mM}$ vanadate, $10 \mu \mathrm{g} / \mathrm{ml}$ aprotinin, $10 \mu \mathrm{g} / \mathrm{ml}$ leupeptin and $2 \mathrm{mM}$ phenylmethylsulphonyl fluoride. The protein content was quantified using the Bradford protein assay according to the manufacturer's instructions (Bio-Rad). Proteins were separated by SDS-PAGE and transferred to nitrocellulose membranes (Schleicher \& Schuell, Dassel, Germany). Membranes were blocked with rinsing buffer $(10 \mathrm{mM}$ Tris, $150 \mathrm{mM} \mathrm{NaCl}$ and $0.05 \%$ Tween (v/v), $\mathrm{pH}$ $7 \cdot 2)$ including $3 \% \mathrm{BSA}(\mathrm{w} / \mathrm{v})$ at $4{ }^{\circ} \mathrm{C}$ overnight. For the detection of proteins, membranes were exposed to specific primary antibodies against the nuclear receptors $\mathrm{GR}$ and $\mathrm{MR}$ or the differentiation markers Pref-1, C/EBP $\alpha$ (CEBPA) and aP2. Gel loading was normalised using actin as a control protein. Protein bands were visualised using chemiluminescence (Perkin Elmer, Rodgau-Jügesheim, Germany). The subsequent quantification was performed using Quantity One software (Bio-Rad). Representative western blots are shown using actin as a loading control.

\section{Genomic DNA isolation}

Genomic DNA was extracted from cultured preadipocytes of newly generated adipose cell lines using the Genomic DNA Purification Kit from Gentra Systems (Minneapolis, MN, USA) in accordance with the manufacturer's instruction.

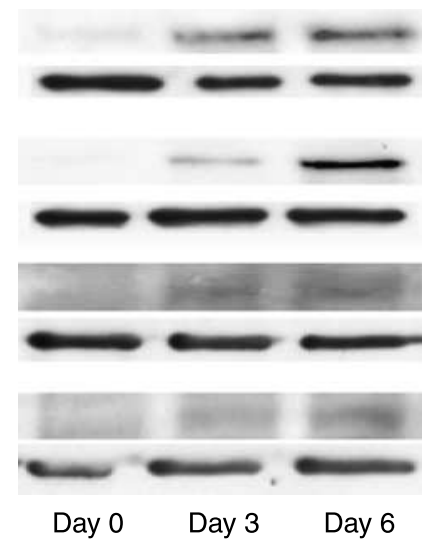

GR in WT white adipocytes Actin control

GR in WT brown adipocytes

Actin control

$M R$ in WT white adipocytes

Actin control

MR in WT brown adipocytes

Actin control

Figure 1 Expression of GR and MR in white and brown adipocytes during differentiation. Protein levels were determined by western blot analysis on days 0,3 and 6 of adipocyte differentiation. Representative western blots of three independent experiments are illustrated.

\section{$R N A$ isolation and reverse transcription}

Total RNA was isolated using QIAzol reagent (Qiagen). To optimise RNA quality, clean-up and genomic DNA digestion were performed using RNAeasy kit and RNaseFree DNase Set (Qiagen). Standardised RNA amounts of $2 \mu \mathrm{g}$ were reverse-transcribed in a $20 \mu \mathrm{l}$ reaction mixture containing Superscript II (Invitrogen), oligo $\mathrm{p}(\mathrm{dt}) 15$ primers and RNase inhibitor (Roche Molecular Biochemicals).

\section{Quantitative real-time PCR}

Two microlitres of prediluted DNA were amplified in a total volume of $12 \mu \mathrm{l}$ containing $1 \times$ SYBR Premix Ex Taq (TaKaRa, Otsu, Japan) and gene-specific primers using the Mastercycler ep realplex (Eppendorf, Hamburg, Germany). Quantitative real-time PCR was performed as follows: initial denaturation at $95{ }^{\circ} \mathrm{C}$ for $300 \mathrm{~s}, 40$ cycles at $95^{\circ} \mathrm{C}$ for $20 \mathrm{~s}$, $60{ }^{\circ} \mathrm{C}$ for $30 \mathrm{~s}$. Amplification of the genomic GR-DNA was carried out using: initial denaturation at $95^{\circ} \mathrm{C}$ for $10 \mathrm{~min}$, 40 cycles at $95^{\circ} \mathrm{C}$ for $30 \mathrm{~s}, 69 \cdot 1^{\circ} \mathrm{C}$ for $1 \mathrm{~min}$ and a final elongation step at $68^{\circ} \mathrm{C}$ for $1 \mathrm{~min}$. For detecting the genomic $M R-D N A$, the following PCR programme was used: initial denaturation at $95^{\circ} \mathrm{C}$ for $10 \mathrm{~min}, 40$ cycles at $95^{\circ} \mathrm{C}$ for $30 \mathrm{~s}$, $67 \cdot 1{ }^{\circ} \mathrm{C}$ for $1 \mathrm{~min}$ and $72{ }^{\circ} \mathrm{C}$ for $1 \mathrm{~min}$. The identity of gene products was verified by melting curve analysis and agarose gel electrophoresis. For optimised relative quantification, 36B4 served as a housekeeping gene. Primer sequences are available upon request.

\section{Determination of leptin concentrations}

Leptin concentrations were determined using the RayBio Mouse Leptin ELISA Kit (RayBiotech, Norcross, GA, USA) according to the manufacturer's manual. 


\section{Oil Red O staining}

Cells were cultivated in $10-\mathrm{cm}$ plates and fat-specific staining was performed with Oil Red $\mathrm{O}$ after induction on days 0,3 and 6 . For this purpose, adipocytes were washed twice with PBS and were subsequently fixed with $10 \%$ formalin $(\mathrm{v} / \mathrm{v})$ for at least $15 \mathrm{~min}$. Afterwards, cells were exposed to Oil Red $\mathrm{O}$ for $1 \mathrm{~h}$ at room temperature (stock solution: $0 \cdot 5 \mathrm{~g}$ Oil Red $\mathrm{O}$ in $100 \mathrm{ml}$ isopropanol; working
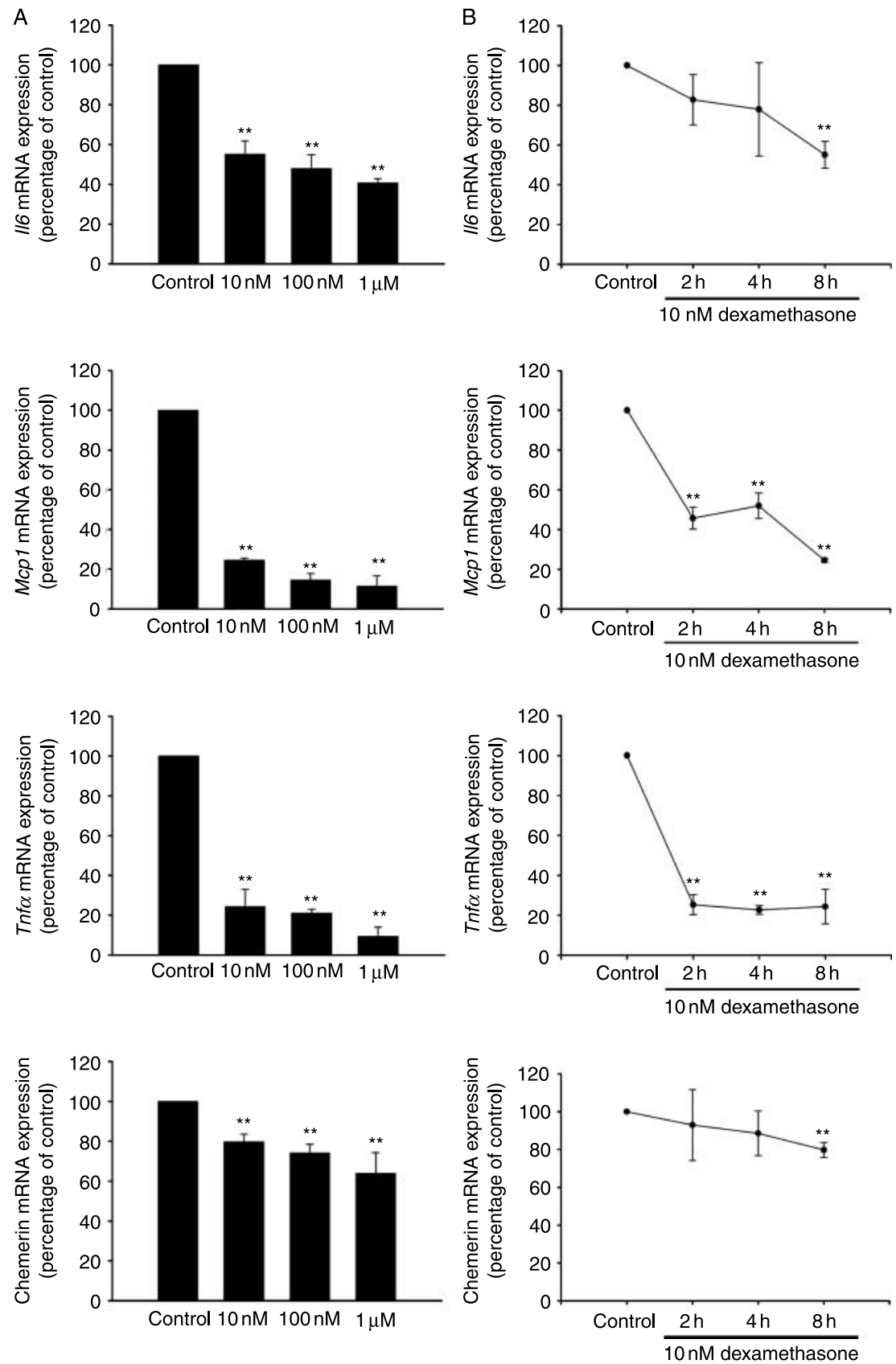

Figure 2 (A) Dose-dependent inhibition of 116, Mcp1, Tnf $\alpha$ and chemerin in differentiated white adipocytes by dexamethasone. Adipocytes were treated with $10 \mathrm{nM}, 100 \mathrm{nM}$ and $1 \mu \mathrm{M}$ for $8 \mathrm{~h}$ or left untreated. mRNA expression was quantified by RT-PCR. (B) Time-dependent decrease of II6, Mcp1, Tnf $\alpha$ and chemerin in differentiated white adipocytes by dexamethasone. Cells were exposed to $10 \mathrm{nM}$ dexamethasone for 2, 4 and $8 \mathrm{~h}$. Gene expression was measured by RT-PCR. Results are shown as mean \pm S.E.M. of three independent experiments. ${ }^{* *} P \leq 0 \cdot 01$ comparing non-treated cells to dexamethasone-treated cells. 


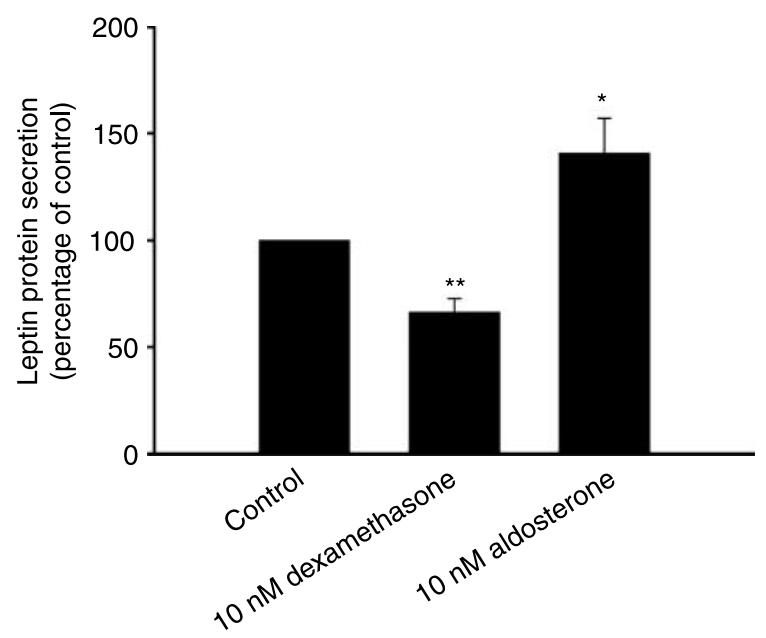

Figure 3 Reciprocal regulation of leptin secretion by dexamethasone and aldosterone. Adipocytes were treated with $10 \mathrm{nM}$ dexamethasone or aldosterone for $24 \mathrm{~h}$ or left untreated. Protein concentrations were quantified by ELISA analyses. Results are shown as mean \pm S.E.M. of at least three independent experiments. ${ }^{*} P \leq 0 \cdot 05$ and ${ }^{* *} P \leq 0 \cdot 01$ comparing non-treated cells to treated cells.

solution: $60 \%$ stock solution (v/v) and $\left.40 \% \mathrm{H}_{2} \mathrm{O}(\mathrm{v} / \mathrm{v})\right)$. To remove the staining solution, cells were washed several times with distilled water. Representative macroscopic as well as microscopic pictures at a 40-fold magnification were taken using a digital camera (Olympus E330, Olympus Imaging Europa, Hamburg, Germany). For densitometric analysis, Oil Red O stain was removed by washing cells with isopropanol for $15 \mathrm{~min}$. Optical density was measured at $500 \mathrm{~nm}$.
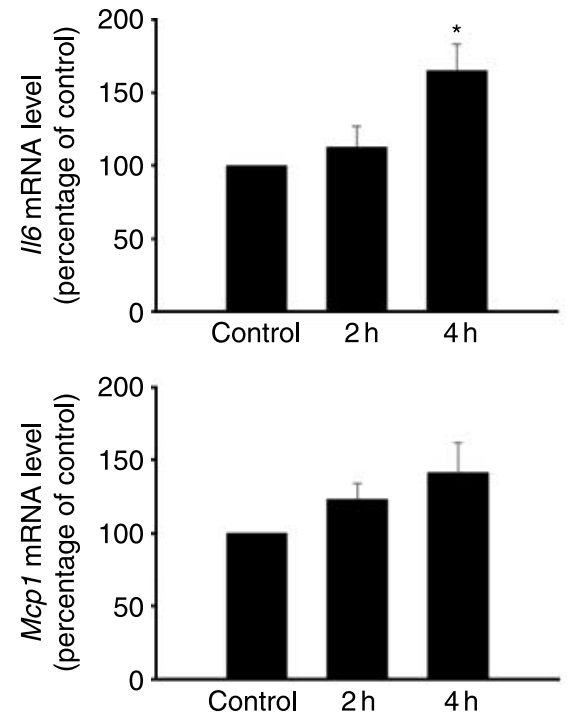

\section{Statistical analysis}

Statistical analyses were performed with Sigma Plot (SPSS Science, Chicago, IL, USA). Results are presented as mean values \pm s.E.M. Statistical significance was determined using the unpaired Student's $t$-test. $P$ values $\leq 0.05$ were considered significant, and those $\leq 0.01$ were considered highly significant.

\section{Results}

GR and MR are expressed in white and brown adipocytes and are up-regulated during adipocyte differentiation

Both the GR and the MR were expressed in white adipocytes as well as in brown adipocytes. Protein analysis revealed an increase in the expression of both receptors during adipogenesis (Fig. 1).

Selective GR stimulation with dexamethasone inhibits the expression of pro-inflammatory adipokines

To define the role of the corticosteroid receptors MR and GR in mediating an inflammatory adipokine response in white adipose tissue, we first investigated the effect of selective GR stimulation on the adipokine profile. Acute dexamethasone treatment of fully differentiated white adipocytes dose- and time-dependently inhibited mRNA expression of the proinflammatory adipokines Il6, Mcp 1, Tnfo and chemerin.

Il6 mRNA concentrations were dose-dependently decreased by up to $60 \%$ after stimulation with dexamethasone for $8 \mathrm{~h}$ (Fig. 2A). Furthermore, the inhibitory effect of
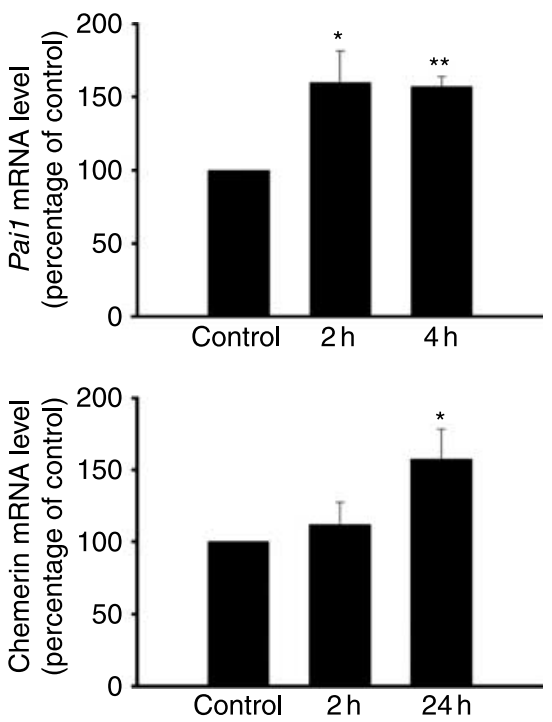

Figure 4 Time-dependent regulation of II6, Mcp1, Pai1 and chemerin gene expression in differentiated white adipocytes by aldosterone. Adipocytes were treated with $10 \mathrm{nM}$ aldosterone for 2,4 and $24 \mathrm{~h}$ or left untreated. mRNA expression of $I 16, M c p 1$, Pai1 and chemerin was analysed by RT-PCR. Results are shown as mean \pm S.E.M. of at least three independent experiments. ${ }^{*} P \leq 0 \cdot 05$ and ${ }^{* *} P \leq 0 \cdot 01$ comparing non-treated cells to aldosterone-treated cells. 

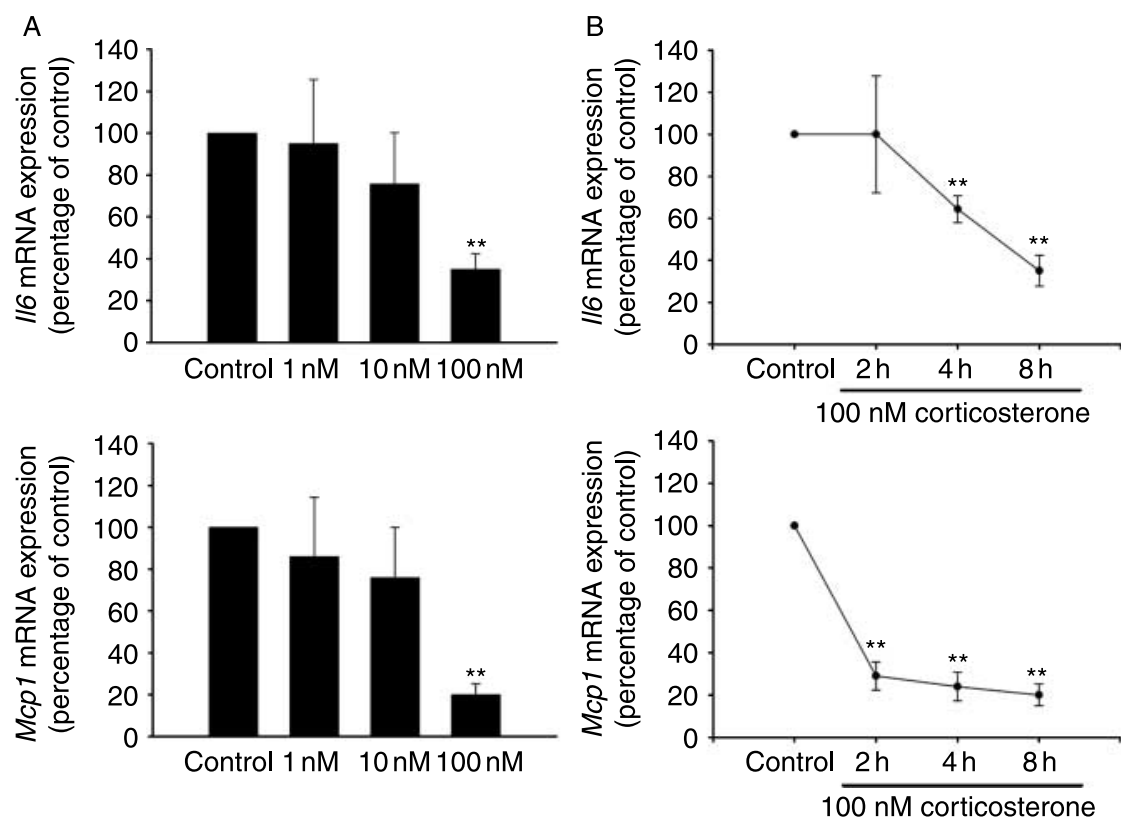

Figure 5 (A) Dose-dependent inhibition of $1 / 6$ and Mcp1 gene expression in differentiated white adipocytes by corticosterone. Adipocytes were treated with 1, 10 and $100 \mathrm{nM}$ corticosterone for $8 \mathrm{~h}$ or left untreated. mRNA expression was quantified by RT-PCR. (B) Time-dependent decrease of $1 / 6$ and Mcp1 in differentiated white adipocytes by corticosterone. Cells were exposed to $100 \mathrm{nM}$ corticosterone for 2, 4 and $8 \mathrm{~h}$. Gene expression was measured by RT-PCR. Results are shown as mean \pm S.E.M. of three independent experiments. ${ }^{* *} P \leq 0 \cdot 01$ comparing non-treated cells to corticosterone-treated cells.

dexamethasone was time-dependent. Il6 gene expression was slightly reduced by $20 \%$ after $2 \mathrm{~h}$ in response to $10 \mathrm{nM}$ dexamethasone treatment and reached a maximal reduction by $45 \%$ after 8 h (Fig. 2B).

Similarly, selective GR stimulation with dexamethasone for $8 \mathrm{~h}$ markedly suppressed the gene expression of the proinflammatory adipokine $\mathrm{MCP} 1$ in terminally differentiated adipocytes (Fig. 2A). A maximal decrease of MCP1 mRNA by $90 \%$ was observed when adipocytes were stimulated with $1 \mu \mathrm{M}$ dexamethasone (Fig. 2A). Exposure of adipocytes to $10 \mathrm{nM}$ dexamethasone for $2 \mathrm{~h}$ markedly suppressed MCP1 mRNA expression by $55 \%$ as compared to non-treated cells. The gene expression time-dependently declined and was maximally decreased by $75 \%$ after 8 h (Fig. 2B).

Treatment with dexamethasone also resulted in a significant reduction of the pro-inflammatory adipokine TNF- $\alpha$. Gene expression of Tnfo was maximally decreased by $90 \%$ after exposure to $1 \mu \mathrm{M}$ dexamethasone for $8 \mathrm{~h}$ (Fig. 2A). Even low concentrations of dexamethasone (10 $\mathrm{nM}$ ) strongly suppressed the mRNA expression by $\sim 75 \%$ after 2,4 and 8 h (Fig. $2 A$ ).

Moreover, GR activation by dexamethasone decreased mRNA levels of the novel pro-inflammatory adipokine chemerin. Chemerin gene expression was dose-dependently suppressed by up to $35 \%$ after treatment with $10 \mathrm{nM}-1 \mu \mathrm{M}$ dexamethasone for $8 \mathrm{~h}$ in terminally differentiated white adipocytes (Fig. 2A). The inhibitory effect was time-dependent (Fig. 2B).
Leptin was recently shown to be involved in immune responses as a pro-inflammatory factor. Exposure of differentiated adipocytes to $10 \mathrm{nM}$ dexamethasone for $24 \mathrm{~h}$ significantly decreased the protein secretion of leptin by $35 \%$ when compared to untreated cells (Fig. 3).

Selective MR stimulation with aldosterone promotes a pro-inflammatory and diabetogenic adipokine expression profile

In contrast to the findings described above, selective MR stimulation of mature white adipocytes with low concentrations of aldosterone induced the gene expression of the pro-inflammatory adipokines $I l 6$ and Pai1, while $M c p 1$ was unaffected. Gene expression of $I l 6$ tended to be increased by $15 \%$ after $2 \mathrm{~h}$ of $10 \mathrm{nM}$ aldosterone treatment and was maximally elevated by $65 \%$ after $4 \mathrm{~h}$ as compared to nontreated cells (Fig. 4). Similar pro-inflammatory effects of MR stimulation were observed with regard to Pail gene expression. The mRNA expression level of this adipokine was enhanced by about $60 \%$ after 2 and $4 \mathrm{~h}$ of treatment with $10 \mathrm{nM}$ aldosterone in terminally differentiated white adipocytes (Fig. 4). There was a non-significant trend towards an up-regulation of $M c p 1$ gene expression by 25 and $40 \%$ as compared to non-treated cells after 2 and $4 \mathrm{~h}$ of treatment with $10 \mathrm{nM}$ aldosterone (Fig. 4). Gene expression levels of the pro-inflammatory adipokine chemerin were slightly elevated by $10 \%$ after MR activation by $10 \mathrm{nM}$ aldosterone for $2 \mathrm{~h}$ and 

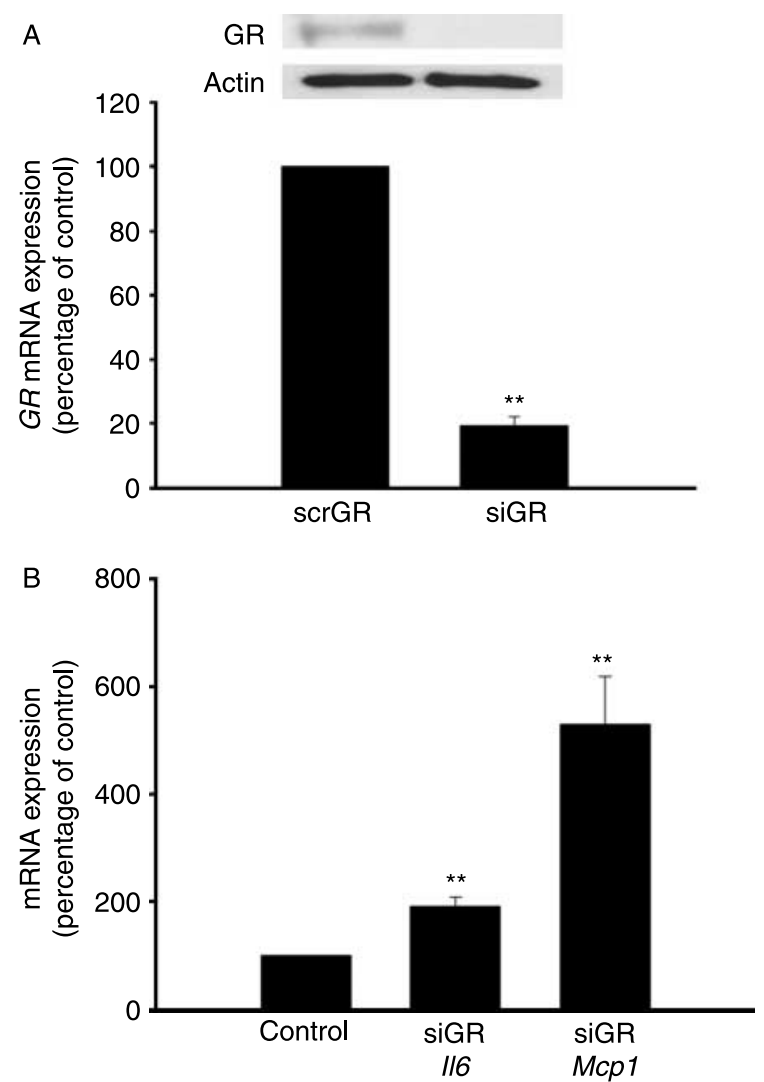

Figure 6 (A) Validation of $G R$ knockdown in fully differentiated white adipocytes. Acute knockdown of the GR was performed on day 3 of adipocyte differentiation. On day 6, mRNA expression as well as protein expression of the GR was determined by RT-PCR and western blot. (B) Increase of $1 / 6$ and Mcp1 in GR knockdown adipocytes by corticosterone. GR knockdown was performed in white adipocytes on day 3 of adipocyte differentiation. Seventy-two hours after transfection with specific siGR or scrRNA, adipocytes were treated with $100 \mathrm{nM}$ corticosterone for $2 \mathrm{~h}$. mRNA expression of $1 / 6$ and Mcp1 was analysed by RT-PCR. Results are shown as mean \pm S.E.M. of three independent experiments. ${ }^{* *} P \leq 0 \cdot 01$ comparing scrRNA-treated control cells to siGR-treated cells.

were maximally increased by $60 \%$ after 24 h (Fig. 4). Finally, protein secretion of the pro-inflammatory factor leptin revealed an up-regulation by $40 \%$ after stimulation with $10 \mathrm{nM}$ aldosterone for $24 \mathrm{~h}$ (Fig. 3).

Unselective stimulation of corticosteroid receptors in adipocytes with corticosterone decreased the expression of pro-inflammatory adipokines

To investigate whether the anti-inflammatory GR-mediated effect or the mainly pro-inflammatory effect of the MR predominates the response to the unselective corticosteroid receptor agonist corticosterone in adipocytes, we investigated the effect of corticosterone on the adipokine profile. Whereas low concentrations of corticosterone did not have a significant effect on the gene expression of Il6 and Mcp1, treatment with higher corticosterone concentrations resulted in a decrease of these pro-inflammatory adipokines (Fig. 5A). This suppression was time-dependent and reached a maximal reduction of 16 and Mcp 1 gene expression after $8 \mathrm{~h}$ by 65 and $80 \%$ respectively (Fig. 5B).

GR knockdown and MR stimulation by corticosterone in mature white adipocytes lead to an increase in $\mathrm{Il} 6$ and Mcp1 gene expression

We further examined the effect of an acute $G R$ knockdown in fully differentiated white adipocytes on the adipokine profile. Western blot and mRNA expression analyses confirmed the GR down-regulation by $\sim 80 \%$ in white adipocytes on day 6 of adipocyte differentiation using specific RNA interference (Fig. 6A). Treatment with $100 \mathrm{nM}$ corticosterone for $2 \mathrm{~h}$ increased the gene expression of IL6 by $90 \%$ in siRNA-treated adipocytes when compared to control cells (Fig. 6B). Similarly, the mRNA concentrations of $M c p 1$ in GR-deficient adipocytes were markedly elevated by $430 \%$ after $2 \mathrm{~h}$ (Fig. $6 \mathrm{~B}$ ).

GR knockout adipose cell lines show mildly impaired adipocyte differentiation, while MR knockout preadipocytes completely fail to accumulate lipids

We investigated the different roles of the GR and MR in adipocyte biology by generating novel brown adipose cell lines from newborn homozygous $G R$ and $M R$ knockout
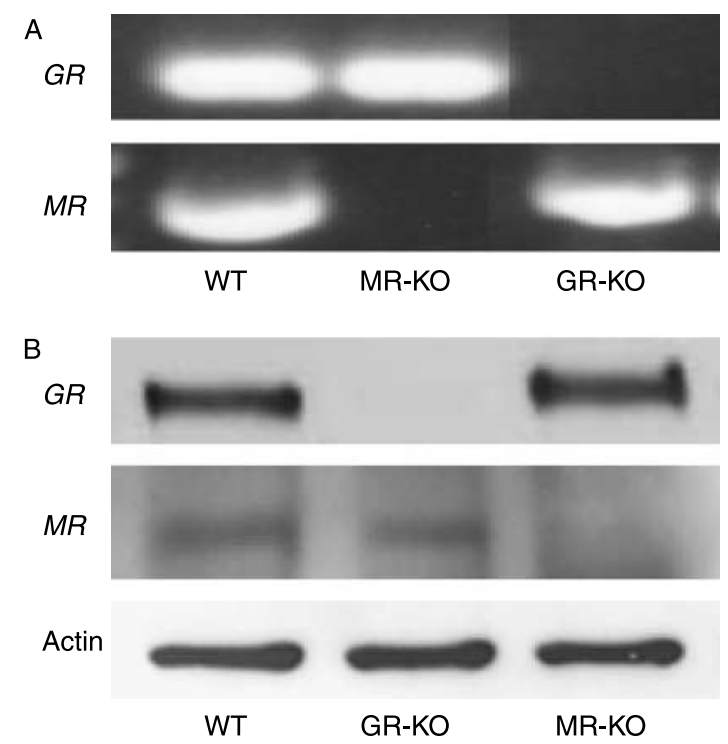

Figure 7 Expression of $G R$ and $M R$ in newly generated wild-type, $G R$ and $M R$ knockout cell lines. (A) Genotyping of wild-type, GR and $M R$ knockout cell lines. Genomic DNA was extracted from cultured cells, amplified by PCR and separated by agarose gel electrophoresis. (B) Validation of $G R$ and $M R$ knockout in the novel adipose cell lines at protein level. Protein expression of GR and MR was detected in fully differentiated adipocytes by western blot analysis. Representative images of three independent experiments are shown. 
mice which die shortly after birth. Genotyping of these cell lines confirmed the absence of the GR and $M R$ gene (Fig. 7A) resulting in a complete lack of GR and MR protein expression respectively as shown by western blot analysis (Fig. 7B). The GR knockout in adipocytes had no effect on the expression of the MR protein. In MR knockout cells, the protein expression of the GR also remained unchanged when compared to wild-type cells (Fig. 7B).

To test whether the receptor deletion had any effect on adipocyte differentiation, the standard differentiation protocol was used, and fat-specific Oil Red $\mathrm{O}$ staining and microscopy were performed on days 0,3 and 6 after induction. Preadipocytes from all newly generated cell lines did not show any differences on microscopic examination (data not shown). However, during the differentiation course, GR knockout adipocytes displayed an impaired accumulation of lipid droplets as compared to the wild-type control cell line (Fig. 8A and B: middle row). Newly generated preadipocytes from $M R$ knockout mice completely failed to accumulate lipid droplets (Fig. 8A and B: bottom row).

GR knockout cell lines showed a considerable decrease of lipid accumulation by $\sim 50 \%$ in early differentiation when compared to wild-type adipocytes as quantified by densitometry (Fig. 8C). This deficit was compensated in later differentiation stages. Densitometric analysis revealed a strong deficit in lipid accumulation by $\sim 70 \%$ in $M R$ knockout cell lines on days 3 and 6 of adipocyte differentiation (Fig. 8C). Pref- 1 , an early inhibitory differentiation marker, was highly up-regulated by $900 \%$ in MR knockout cells (Fig. 8D). Furthermore, immunoblot analysis on day 3 demonstrated a reduction of the differentiation marker $\mathrm{C} / \mathrm{EBP} \alpha$ in MR-deficient cells (Fig. 8D). The late differentiation marker
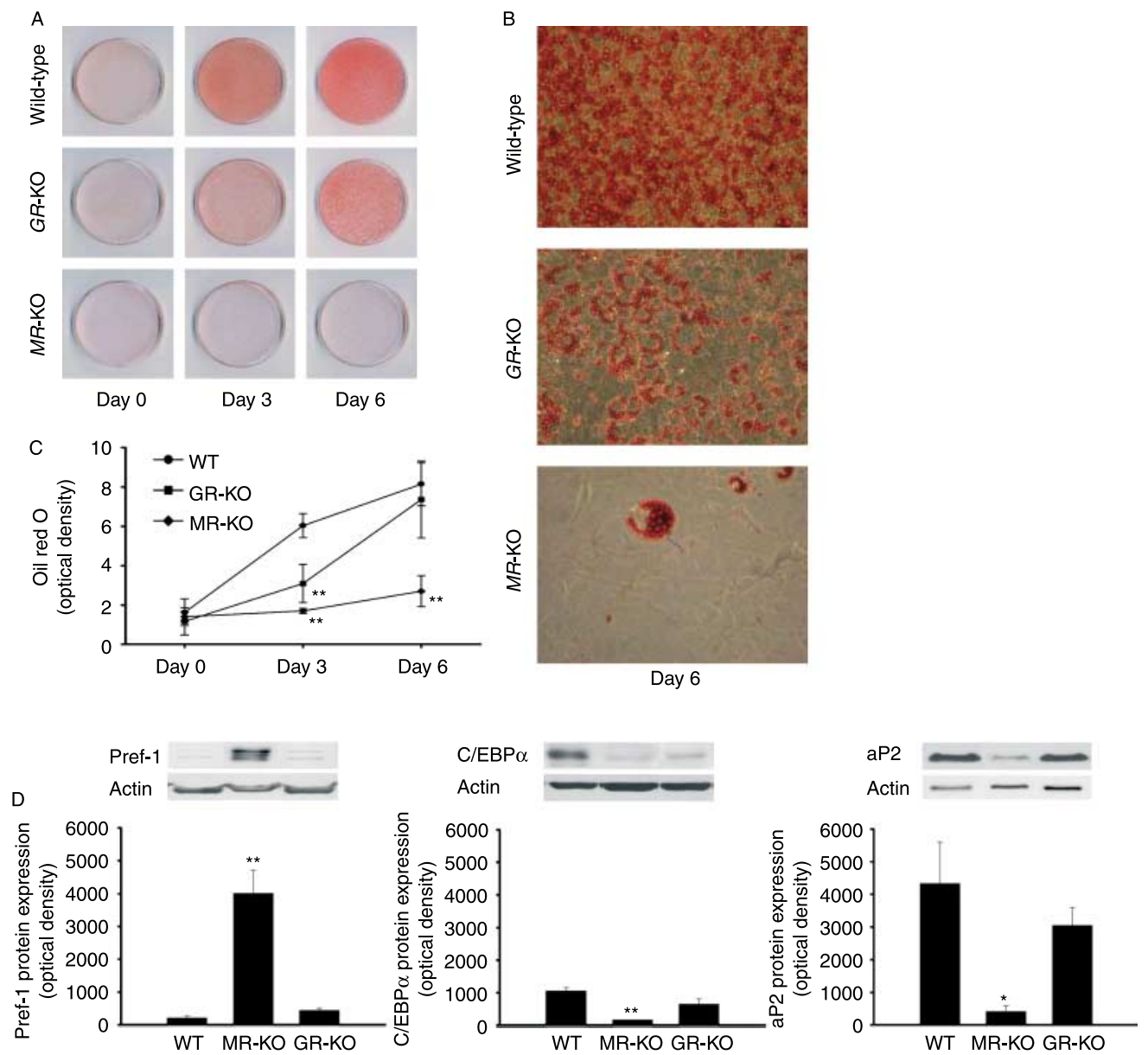

Figure 8 Adipocyte differentiation of newly established $G R$ and $M R$ knockout adipose cell lines. Lipid accumulation in wild-type, $G R$ and $M R$ knockout cell lines was visualised by fat-specific Oil Red $O$ staining. (A) The extent of fat accumulation on days 0,3 and 6 after cell induction. (B) Microscopy images in 40-fold magnification. (C) Densitometric analyses of Oil Red O staining. (D) Protein expression of the differentiation markers Pref-1, C/EBP $\alpha$ and aP2 was determined by immunoblotting on day 3 of adipocyte differentiation. Results are shown as mean \pm S.E.M. of at least three independent experiments. ${ }^{*} P \leq 0 \cdot 05$ and ${ }^{*} P \leq 0 \cdot 01$ comparing wild-type cells to knockout cells. 

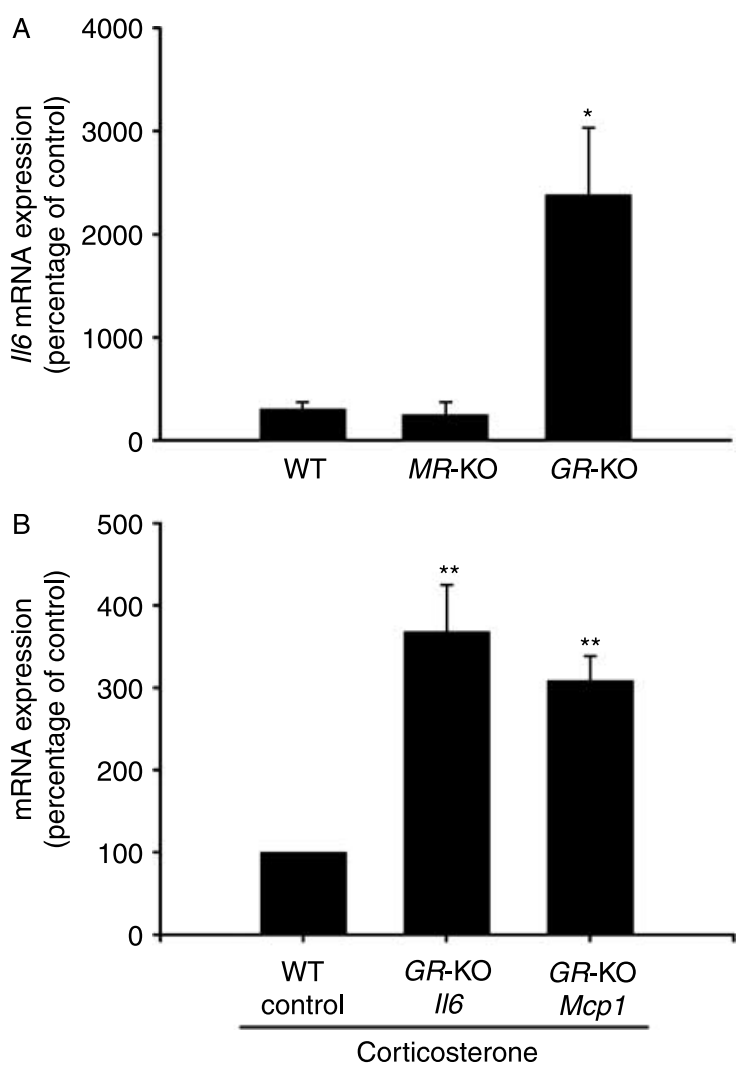

Figure 9 (A) Basal $/ 16$ gene expression in preadipocytes of novel wild-type, $M R$ and $G R$ knockout adipose cell lines. mRNA expression of $/ / 6$ was analysed by RT-PCR. Results are shown as mean \pm s.E.M. of three independent experiments. (B) Stimulation of pro-inflammatory adipokines by corticosterone in $G R$ knockout cell lines. Wild-type and $G R$ knockout cell lines were chronically treated with $100 \mathrm{nM}$ corticosterone during the entire differentiation process. mRNA expression levels of $/ / 6$ and Mcp1 were quantified by RT-PCR. Results are shown as mean \pm s.E.M. of seven independent experiments. ${ }^{*} P \leq 0 \cdot 05$ and ${ }^{*} P \leq 0 \cdot 01$ comparing wild-type cell lines to knockout cells.

aP2 was also markedly decreased by more than $90 \%$ in $M R$ knockout cell lines when compared to the wild-type control (Fig. 8D). No significant differences between GR knockout and wild-type control cell lines were found with regard to the expression of differentiation markers during adipocyte differentiation.

\section{GR knockout leads to a rise in pro-inflammatory adipokines}

To examine the consequences of the GR or MR knockout and the physiological functions of the remaining corticosteroid receptors in these cell lines for the regulation of the adipokine profile, the expression levels of the pro-inflammatory adipokine $I l 6$ in wild-type, $M R$ and GR knockout preadipocytes were analysed. Whereas $I l 6$ expression in $M R$ knockout preadipocytes was unaltered when compared to wild-type cells, GR knockout in preadipocytes resulted in a strong increase of $I l 6$ by $2300 \%$ (Fig. 9A). Furthermore, wild-type and GR knockout adipocytes were chronically exposed to $100 \mathrm{nM}$ corticosterone from day 0 until day 6 of adipocyte differentiation. Subsequent mRNA expression analysis revealed a robust increase of the pro-inflammatory adipokines $I l 6$ and $M c p 1$ by $\sim 270$ and $210 \%$ respectively when compared to the wild-type control (Fig. 9B).

\section{Discussion}

Corticosteroid metabolism in adipose tissue plays a crucial role in the pathogenesis of the metabolic syndrome. Adipose tissue-specific amplification of glucocorticoids induces all the characteristic features of the metabolic syndrome (Masuzaki et al. 2001). Our study for the first time dissects the different metabolic and endocrine roles of the adipose GR and MR in native wild-type, knockdown and newly generated knockout cell lines. Selective GR stimulation of differentiated white adipocytes with dexamethasone considerably inhibited the expression of Il6, Mcp1, Tnfo, chemerin and leptin. By contrast, selective MR stimulation with aldosterone promoted the expression of pro-inflammatory adipokines. These cytokines were also elevated when the GR was acutely knocked down by siRNA or absent in knockout cell lines. Whereas adipocytes from GR knockout mice showed only mildly impaired adipogenesis, especially during early differentiation, $M R$ knockout preadipocytes completely failed to accumulate lipids.

These data newly define the significance of the corticosteroid receptors GR and MR for adipocyte biology by demonstrating opposing effects of the GR and MR in mediating a pro-inflammatory and diabetogenic adipokine response. Furthermore, these data clearly demonstrate the crucial role of the MR for adipocyte differentiation.

To our knowledge, this is the first study to demonstrate that MR activation in fully differentiated white adipocytes promotes the gene expression of important pro-inflammatory adipokines. These data suggest that the MR indirectly impairs insulin sensitivity and promotes atherosclerosis via the stimulation of pro-inflammatory and pro-diabetogenic adipokines in adipose tissue.

These results are in accordance with a recent study illustrating that aldosterone treatment increases the mRNA levels of pro-inflammatory adipokines such as $I l 6$ and Tnf $\alpha$ in undifferentiated preadipocytes (Guo et al. 2008). Consistent with our findings, MR blockade with eplerenone was shown to reverse obesity-associated changes in the expression of proinflammatory adipokines in murine adipose tissue (Guo et al. 2008). Accordingly, spironolactone, an MR antagonist, reduced basal IL6 secretion in human adipose tissue (Corbould 2007). However, in contrast to previous studies in differentiated brown adipocytes and white preadipocytes (Kraus et al. 2005, Guo et al. 2008), in this study there was only a trend towards an up-regulation of $M c p 1$. This may suggest that mature white adipocytes are differentially 
conducive to the pro-inflammatory effect of aldosterone. Interestingly, mineralocorticoid blockade with eplerenone suppressed macrophage infiltration and CD11c, a marker of M1 macrophages, in adipose tissue of obese mice (Hirata et al. 2009). This might be due to the inhibitory effect of eplerenone on the secretion of chemokines in adipocytes. In obese mice, mineralocorticoid blockade by eplerenone markedly reduced the number of hypertrophic adipocytes which are known to have an increased production of pro-inflammatory adipokines (Skurk et al. 2007, Hirata et al. 2009). Furthermore, treatment of obese mice with the MR antagonist eplerenone also improved obesity-associated metabolic disorders such as insulin resistance and hypertriglyceridaemia (Guo et al. 2008, Hirata et al. 2009). These data are in accordance with our findings indicating that the MR plays a crucial role in the regulation of inflammatory and metabolic adipocyte responses.

Clinical data point to the potential implication of the adipose tissue MR in obesity-related inflammation, insulin resistance and cardiovascular complications. An association between plasma aldosterone levels on the one hand and obesity and insulin resistance on the other hand has been demonstrated (Goodfriend et al. 1998, Corry \& Tuck 2003, Colussi et al. 2007, Lastra-Gonzalez et al. 2007, Rossi et al. 2008). Recent studies even describe a higher prevalence of the metabolic syndrome and of cardiovascular events in patients with primary aldosteronism when compared to patients with essential hypertension (Milliez et al. 2005, Fallo et al. 2006, 2007). Treatment of patients with an MR antagonist improved insulin sensitivity and reduced markers of inflammation (Catena et al. 2006, Matsumoto et al. 2006).

In contrast to the MR-mediated pro-inflammatory, prodiabetogenic effect, GR activation strongly inhibited the expression of the pro-inflammatory adipokines Il6, Mcp1, Tnfo, chemerin and leptin in this study. These findings are consistent with recent studies investigating the effect of dexamethasone on the adipokine profile (Fried et al. 1998, Zhang et al. 2001, Vicennati et al. 2002, Fasshauer et al. 2004). Our data provide evidence that the GR has an antiinflammatory effect in adipose tissue. In accordance with these findings, it has been very recently shown by others that glucocorticoids prevent adipocyte-induced recruitment of macrophages into adipose tissue in obese mice (Patsouris et al. 2009). Consistent with our data on the antiinflammatory action of the GR, this inhibitory effect on macrophage accumulation was mediated by the adipocyte GR (Patsouris et al. 2009). Furthermore, the study lends support to the notion that the crosstalk between adipocytes and macrophages via pro-inflammatory adipokines is crucial for the development of obesity-associated subclinical inflammation.

Taking into account the great anti-inflammatory effect of the adipocyte GR, corticosteroid action exclusively via the adipocyte GR does not explain the subclinical inflammatory state seen in obesity. Our data suggest that the adipocyte MR activated by mineralocorticoids as well as by glucocorticoids may be significant for the induction of inflammation in adipose tissue.

Whereas stimulation of wild-type adipocytes with low concentrations of the unselective corticosteroid corticosterone did not significantly regulate the expression of $I l 6$ and $M c p 1$, high concentrations resulted in a suppression of these pro-inflammatory adipokines. These novel data indicate that in a physiological state, in wild-type adipocytes the antiinflammatory response mediated by the GR preponderates. However, given the fact that the MR possesses affinity to glucocorticoids as well as to mineralocorticoids and corticosterone as an unselective agonist also binds to the $M R$, it is likely that the pro-inflammatory $M R$ is simultaneously activated and counteracts the anti-inflammatory GR action. This might potentially explain the rather small anti-inflammatory effect of corticosterone, particularly in low concentrations, when compared to the strong suppression of Il 6 and Mcp 1 by the same concentrations of dexamethasone.

Moreover, we found that $M R$ knockout in adipocytes did not result in a significant regulation of pro-inflammatory adipokines when compared to wild-type cells. Interestingly, GR knockout resulted in a very strong increase of IL6 in preadipocytes. These data underline our hypothesis of a permissive pro-inflammatory effect of the MR whose action in a physiological state appears to be overlapped by the anti-inflammatory GR effect and becomes obvious when the balance between GR and MR expression in adipocytes is altered.

Interestingly, it has recently been shown by others that in obese mice, the $M R$ expression is significantly up-regulated in adipose tissue (Hirata et al. 2009). Furthermore, elevated aldosterone levels were found in obese subjects. These obesityassociated changes may result in an increased activation of the adipocyte $\mathrm{MR}$ in obesity. A disturbance of the balance between GR and MR activation in adipose tissue may potentially decrease anti-inflammatory adipocyte responses and promote pro-inflammatory adipocyte responses in obesity.

However, our study investigating MR and GR action in a cell model cannot test the physiological significance of these findings for the pathophysiology of obesity in human beings. It might hence be of particular interest to investigate obesityinduced changes in GR and MR activation in obese subjects.

Finally, we have characterised newly generated knockout adipose cell lines from newborn homozygous GR and MR knockout mice (Cole et al. 1995, Berger et al. 1998). Since these mice die shortly after birth, immortalised cell lines represent a valuable tool to explore the adipose tissue of these GR- and MR-deficient mice (Klein et al. 2002). This is the first study to reveal the consequences of a complete deletion of the corticosteroid receptors MR and GR in adipocytes. Both dexamethasone and aldosterone have been found to be potent stimulators of adipocyte differentiation (Rondinone et al. 1993, Gregoire 2001). Surprisingly, GR knockout adipocytes mainly showed a deficiency in early differentiation, which was nearly compensated during the differentiation 
course when compared to the wild-type control. In contrast, $M R$ knockout preadipocytes completely failed to accumulate lipids. These findings demonstrate the great significance of the adipose MR for physiological adipocyte differentiation.

In line with our results, several studies have described that aldosterone promotes adipocyte differentiation (Rondinone et al. 1993, Penfornis et al. 2000, Caprio et al. 2007). Moreover, it has been recently reported that the MR antagonist spironolactone and specific MR down-regulation by siRNA inhibit adipocyte differentiation of 3T3-L1 cells (Caprio et al. 2007).

Furthermore, our findings suggest that the GR plays an important role during the early differentiation stage. These data are consistent with the findings from another group demonstrating that GR activation within the first days of adipocyte differentiation is a potent proadipogenic factor in 3T3-L1 cells, while late and long-term stimulation results in an inhibition of the terminal adipogenesis (Caprio et al. 2007).

There is accumulating evidence that corticosteroid action in adipose tissue is mediated by the GR as well as the MR. Our data lend support to a model in which the inflammatory response of adipocytes is highly and oppositely regulated by the activation of the GR and MR by corticosteroids in adipose tissue. The increased secretion of pro-inflammatory adipokines due to an enhanced MR activation in obesity may promote the migration of macrophages into adipose tissue. The release of further cytokines by macrophages might in turn further deteriorate the inflammatory process. Our results suggest that the corticosteroid action in adipose tissue is instrumental in controlling obesity-associated subclinical inflammation which may promote associated metabolic and cardiovascular complications.

In summary, the present study reveals differential and opposite roles of the MR and GR in controlling adipose metabolic and inflammatory responses. Corticosteroid action via the $\mathrm{MR}$ is essential for adipocyte differentiation and promotes a pro-inflammatory and pro-diabetogenic adipokine expression profile. This may play an important role in the pathogenesis of obesity and associated cardiovascular complications. Selective corticosteroid receptor modulation may offer new perspectives for the prevention and treatment of the metabolic syndrome.

\section{Declaration of interest}

The authors declare that there is no conflict of interest that could be perceived as prejudicing the impartiality of the research reported.

\section{Funding}

This work was supported by the Kompetenznetz Adipositas (Competence Network Adipositas) funded by the Federal Ministry of Education and Research (FKZ 01GI0834) and by a grant from the Deutsche Forschungsgemeinschaft (DFG) to JK (KL 1131/4-1).

\section{References}

Alberti L, Girola A, Gilardini L, Conti A, Cattaldo S, Micheletto G \& Invitti C 2007 Type 2 diabetes and metabolic syndrome are associated with increased expression of 11beta-hydroxysteroid dehydrogenase 1 in obese subjects. International Journal of Obesity 31 1826-1831.

Arriza JL, Weinberger C, Cerelli G, Glaser TM, Handelin BL, Housman DE \& Evans RM 1987 Cloning of human mineralocorticoid receptor complementary DNA: structural and functional kinship with the glucocorticoid receptor. Science 237 268-275.

Berger S, Bleich M, Schmid W, Cole TJ, Peters J, Watanabe H, Kriz W, Warth R, Greger R \& Schutz G 1998 Mineralocorticoid receptor knockout mice: pathophysiology of $\mathrm{Na}^{+}$metabolism. PNAS 95 9424-9429.

Bluher M 2008 The inflammatory process of adipose tissue. Pediatric Endocrinology Reviews 6 24-31.

Bujalska IJ, Kumar S \& Stewart PM 1997 Does central obesity reflect "Cushing's disease of the omentum"? Lancet 349 1210-1213.

Caprio M, Feve B, Claes A, Viengchareun S, Lombes M \& Zennaro MC 2007 Pivotal role of the mineralocorticoid receptor in corticosteroid-induced adipogenesis. FASEB Journal 21 2185-2194.

Catena C, Lapenna R, Baroselli S, Nadalini E, Colussi G, Novello M, Favret G, Melis A, Cavarape A \& Sechi LA 2006 Insulin sensitivity in patients with primary aldosteronism: a follow-up study. Journal of Clinical Endocrinology and Metabolism 91 3457-3463.

Cole TJ, Blendy JA, Monaghan AP, Krieglstein K, Schmid W, Aguzzi A, Fantuzzi G, Hummler E, Unsicker K \& Schutz G 1995 Targeted disruption of the glucocorticoid receptor gene blocks adrenergic chromaffin cell development and severely retards lung maturation. Genes and Development 9 1608-1621.

Colussi G, Catena C, Lapenna R, Nadalini E, Chiuch A \& Sechi LA 2007 Insulin resistance and hyperinsulinemia are related to plasma aldosterone levels in hypertensive patients. Diabetes Care 30 2349-2354.

Corbould A 2007 Effects of spironolactone on glucose transport and interleukin-6 secretion in adipose cells of women. Hormone and Metabolic Research 39 915-918.

Corry DB \& Tuck ML 2003 The effect of aldosterone on glucose metabolism. Current Hypertension Reports 5 106-109.

Engeli S, Bohnke J, Feldpausch M, Gorzelniak K, Heintze U, Janke J, Luft FC \& Sharma AM 2004 Regulation of 11 beta-HSD genes in human adipose tissue: influence of central obesity and weight loss. Obesity Research 12 9-17.

Fallo F, Veglio F, Bertello C, Sonino N, Della Mea P, Ermani M, Rabbia F, Federspil G \& Mulatero P 2006 Prevalence and characteristics of the metabolic syndrome in primary aldosteronism. Journal of Clinical Endocrinology and Metabolism 91 454-459.

Fallo F, Federspil G, Veglio F \& Mulatero P 2007 The metabolic syndrome in primary aldosteronism. Current Hypertension Reports 9 106-111.

Fasshauer M, Klein J, Kralisch S, Klier M, Lossner U, Bluher M \& Paschke R 2004 Monocyte chemoattractant protein 1 expression is stimulated by growth hormone and interleukin-6 in 3T3-L1 adipocytes. Biochemical and Biophysical Research Communications 317 598-604.

Fernandez-Real JM \& Ricart W 2003 Insulin resistance and chronic cardiovascular inflammatory syndrome. Endocrine Reviews 24 278-301.

Fried SK, Bunkin DA \& Greenberg AS 1998 Omental and subcutaneous adipose tissues of obese subjects release interleukin-6: depot difference and regulation by glucocorticoid. Journal of Clinical Endocrinology and Metabolism 83 847-850.

Goodfriend TL, Egan BM \& Kelley DE 1998 Aldosterone in obesity. Endocrine Research 24 789-796.

Gregoire FM 2001 Adipocyte differentiation: from fibroblast to endocrine cell. Experimental Biology and Medicine 226 997-1002.

Guo C, Ricchiuti V, Lian BQ, Yao TM, Coutinho P, Romero JR, Li J, Williams GH \& Adler GK 2008 Mineralocorticoid receptor blockade reverses obesity-related changes in expression of adiponectin, peroxisome proliferator-activated receptor-gamma, and proinflammatory adipokines. Circulation 117 2253-2261. 
Hirata A, Maeda N, Hiuge A, Hibuse T, Fujita K, Okada T, Kihara S, Funahashi T \& Shimomura I 2009 Blockade of mineralocorticoid receptor reverses adipocyte dysfunction and insulin resistance in obese mice. Cardiovascular Research 84 164-172.

Hotamisligil GS, Shargill NS \& Spiegelman BM 1993 Adipose expression of tumor necrosis factor-alpha: direct role in obesity-linked insulin resistance. Science 259 87-91.

Hotamisligil GS, Arner P, Caro JF, Atkinson RL \& Spiegelman BM 1995 Increased adipose tissue expression of tumor necrosis factor-alpha in human obesity and insulin resistance. Journal of Clinical Investigation 95 2409-2415.

Kanda H, Tateya S, Tamori Y, Kotani K, Hiasa K, Kitazawa R, Kitazawa S, Miyachi H, Maeda S, Egashira K et al. 2006 MCP-1 contributes to macrophage infiltration into adipose tissue, insulin resistance, and hepatic steatosis in obesity. Journal of Clinical Investigation 116 1494-1505.

Kern PA, Ranganathan S, Li C, Wood L \& Ranganathan G 2001 Adipose tissue tumor necrosis factor and interleukin-6 expression in human obesity and insulin resistance. American Journal of Physiology. Endocrinology and Metabolism 280 E745-E751.

Kershaw EE, Morton NM, Dhillon H, Ramage L, Seckl JR \& Flier JS 2005 Adipocyte-specific glucocorticoid inactivation protects against dietinduced obesity. Diabetes 54 1023-1031.

Klein J, Fasshauer M, Ito M, Lowell BB, Benito M \& Kahn CR 1999 $\beta(3)$-Adrenergic stimulation differentially inhibits insulin signaling and decreases insulin-induced glucose uptake in brown adipocytes. Journal of Biological Chemistry 274 34795-34802.

Klein J, Fasshauer M, Klein HH, Benito M \& Kahn CR 2002 Novel adipocyte lines from brown fat: a model system for the study of differentiation, energy metabolism, and insulin action. BioEssays 24 382-388.

Kraus D, Jager J, Meier B, Fasshauer M \& Klein J 2005 Aldosterone inhibits uncoupling protein-1, induces insulin resistance, and stimulates proinflammatory adipokines in adipocytes. Hormone and Metabolic Research 37 455-459.

Lastra-Gonzalez G, Manrique-Acevedo C \& Sowers JR 2007 New trends in insulin resistance: the role of mineralocorticoids. Journal of the Cardiometabolic Syndrome 2 233-234.

Mariniello B, Ronconi V, Rilli S, Bernante P, Boscaro M, Mantero F \& Giacchetti G 2006 Adipose tissue 11beta-hydroxysteroid dehydrogenase type 1 expression in obesity and Cushing's syndrome. European Journal of Endocrinology 155 435-441.

Masuzaki H, Paterson J, Shinyama H, Morton NM, Mullins JJ, Seckl JR \& Flier JS 2001 A transgenic model of visceral obesity and the metabolic syndrome. Science 294 2166-2170.

Masuzaki H, Yamamoto H, Kenyon CJ, Elmquist JK, Morton NM, Paterson JM, Shinyama H, Sharp MG, Fleming S, Mullins JJ et al. 2003 Transgenic amplification of glucocorticoid action in adipose tissue causes high blood pressure in mice. Journal of Clinical Investigation 112 83-90.

Matsumoto S, Takebayashi K \& Aso Y 2006 The effect of spironolactone on circulating adipocytokines in patients with type 2 diabetes mellitus complicated by diabetic nephropathy. Metabolism 55 1645-1652.

Mertens I \& Van Gaal LF 2002 Obesity, haemostasis and the fibrinolytic system. Obesity Reviews 3 85-101.

Milliez P, Girerd X, Plouin PF, Blacher J, Safar ME \& Mourad JJ 2005 Evidence for an increased rate of cardiovascular events in patients with primary aldosteronism. Journal of the American College of Cardiology 45 1243-1248.

Morton NM, Paterson JM, Masuzaki H, Holmes MC, Staels B, Fievet C, Walker BR, Flier JS, Mullins JJ \& Seckl JR 2004 Novel adipose tissue-mediated resistance to diet-induced visceral obesity in 11 betahydroxysteroid dehydrogenase type 1-deficient mice. Diabetes 53 931-938.

Patsouris D, Neels JG, Fan W, Li PP, Nguyen MT \& Olefsky JM 2009 Glucocorticoids and thiazolidinediones interfere with adipocyte-mediated macrophage chemotaxis and recruitment. Journal of Biological Chemistry 284 31223-31235.

Paulsen SK, Pedersen SB, Fisker S \& Richelsen B 2007 11Beta-HSD type 1 expression in human adipose tissue: impact of gender, obesity, and fat localization. Obesity 15 1954-1960.
Penfornis P, Viengchareun S, Le Menuet D, Cluzeaud F, Zennaro MC \& Lombes M 2000 The mineralocorticoid receptor mediates aldosteroneinduced differentiation of T37i cells into brown adipocytes. American Journal of Physiology. Endocrinology and Metabolism 279 E386-E394.

Pickup JC \& Crook MA 1998 Is type II diabetes mellitus a disease of the innate immune system? Diabetologia 41 1241-1248.

Pradhan AD, Manson JE, Rifai N, Buring JE \& Ridker PM 2001 C-reeactive protein, interleukin 6 , and risk of developing type 2 diabetes mellitus. Journal of the American Medical Association 286 327-334.

Rondinone CM, Rodbard D \& Baker ME 1993 Aldosterone stimulated differentiation of mouse 3T3-L1 cells into adipocytes. Endocrinology 132 2421-2426.

Rossi GP, Belfiore A, Bernini G, Fabris B, Caridi G, Ferri C, Giacchetti G, Letizia C, Maccario M, Mannelli M et al. 2008 Body mass index predicts plasma aldosterone concentrations in overweight-obese primary hypertensive patients. Journal of Clinical Endocrinology and Metabolism $\mathbf{9 3}$ 2566-2571.

Seckl JR, Morton NM, Chapman KE \& Walker BR 2004 Glucocorticoids and 11 beta-hydroxysteroid dehydrogenase in adipose tissue. Recent Progress in Hormone Research 59 359-393.

Skurk T, Alberti-Huber C, Herder C \& Hauner H 2007 Relationship between adipocyte size and adipokine expression and secretion. Journal of Clinical Endocrinology and Metabolism 92 1023-1033.

Spranger J, Kroke A, Mohlig M, Hoffmann K, Bergmann MM, Ristow M, Boeing H \& Pfeiffer AF 2003 Inflammatory cytokines and the risk to develop type 2 diabetes: results of the prospective population-based European Prospective Investigation into Cancer and Nutrition (EPIC)-Potsdam Study. Diabetes 52 812-817.

Takahashi K, Mizuarai S, Araki H, Mashiko S, Ishihara A, Kanatani A, Itadani H \& Kotani H 2003 Adiposity elevates plasma MCP-1 levels leading to the increased CD11b-positive monocytes in mice. Journal of Biological Chemistry 278 46654-46660.

Vicennati V, Vottero A, Friedman C \& Papanicolaou DA 2002 Hormonal regulation of interleukin-6 production in human adipocytes. International Journal of Obesity and Related Metabolic Disorders 26 905-911.

Viengchareun S, Penfornis P, Zennaro MC \& Lombes M 2001 Mineralocorticoid and glucocorticoid receptors inhibit UCP expression and function in brown adipocytes. American Journal of Physiology. Endocrinology and Metabolism 280 E640-E649.

Wellen KE \& Hotamisligil GS 2005 Inflammation, stress, and diabetes. Journal of Clinical Investigation 115 1111-1119.

Yang K, Khalil MW, Strutt BJ \& Killinger DW 199711 beta-Hydroxysteroid dehydrogenase 1 activity and gene expression in human adipose stromal cells: effect on aromatase activity. Journal of Steroid Biochemistry and Molecular Biology 60 247-253.

Yudkin JS 2003 Adipose tissue, insulin action and vascular disease: inflammatory signals. International Journal of Obesity and Related Metabolic Disorders 27 (Suppl 3) S25-S28.

Zennaro MC, Le Menuet D, Viengchareun S, Walker F, Ricquier D \& Lombes M 1998 Hibernoma development in transgenic mice identifies brown adipose tissue as a novel target of aldosterone action. Journal of Clinical Investigation 101 1254-1260.

Zhang HH, Kumar S, Barnett AH \& Eggo MC 2001 Dexamethasone inhibits tumor necrosis factor-alpha-induced apoptosis and interleukin-1 beta release in human subcutaneous adipocytes and preadipocytes. Journal of Clinical Endocrinology and Metabolism 86 2817-2825.

Received in final form 13 November 2009

Accepted 25 November 2009

Made available online as an Accepted Preprint 25 November 2009 